\title{
PENERAPAN METODE KOOPERATIF MODEL TAPPS SEBAGAI UPAYA MENINGKATKAN PRESTASI BELAJAR PRAKARYA MATERI PENGOLAHAN PANGAN BUAH DAN SAYURAN PADA SISWA KELAS VII B SMP NEGERI 3 CANDIPURO
}

\author{
Khusnul Khotimah,S.Pd ${ }^{1)}$ \\ 1) SMP Negeri 3 Candipuro
}

\begin{abstract}
ABSTRAK: Pembelajaran prakarya penyerapan informasi bukan menjadi trolak ukur utama dalam pembelajaran, akan tetapi perlu juga diimbangi dengan pengembangan dan pemrosesan informasi. Untuk itu aktivitas peserta didik perlu ditingkatkan dalam pemberian latihan dan tugas prakarya dengan berbasis pada kerja kelompok yang mana pada kelompok tersebut mereka bisa menjelaskan ide mereka di dalam anggota kelompok ataupun di luar anggota kelompok. tujuan dari penelitian ini adalah: untuk mengetahui peningkatan prestasi belajar siswa setelah diterapkannya metode pembelajaran kooperatif model TAPPS dan untuk mengetahui pengaruh motivasi belajar siswa setelah diterapkan metode pembelajaran kooperatif model TAPPS. Subyek dari penilitan ini adalah siswa kelas VII B dengan jumlah 25 siswa. Penelitian ini menggunakan penelitian tindakan (action research) sebanyak tiga putaran. Setiap putaran terdiri dari empat tahap yaitu: rancangan, kegiatan dan pengamatan, refleksi, dan refisi. Sasaran penelitian ini adalah siswa kelas VII B SMP Negeri 3 Candipuro Semester Ganjil Tahun Pelajaran 2014 - 2015. Data yang diperoleh berupa hasil tes formatif, lembar observasi kegiatan belajar mengajar. Dari hasil analis didapatkan bahwa prestasi belajar siswa mengalami peningkatan dari siklus I sampai siklus III yaitu, siklus I $(68,00 \%)$, siklus II $(76,00 \%)$, siklus III $(88,00 \%)$. Kesimpulan dari penelitian ini adalah metode kooperatif model TAPPS dapat berpengaruh positif terhadap motivasi belajar Siswa kelas VII B SMP Negeri 3 Candipuro Semester Ganjil Tahun Pelajaran 2014 - 2015, serta model pembelajaran ini dapat digunakan sebagai salah satu alternatif pembelajaran Prakarya.

Kata kunci : Prakarya, Metode Kooperatif, Tapps.
\end{abstract}

ABSTRACT: In craft subjects, information absorption is not the main measure of learning, but needs to be balanced with the development and processing of information. For this reason student activities need to be increased in the provision of exercise and work assignments based on group work where in the group they can explain their ideas within group members or outside group members. The purpose of this study is: to determine the increase in student learning achievement after the application of the TAPPS model of cooperative learning and to determine the effect of student motivation after applying the TAPPS model of cooperative learning. The subjects of this study were students of class VII B with a total of 25 students. This study uses a three-round action research. Each round consists of four stages: design, activity and observation, reflection, and refinement. The target of this research is students of class VII B Candipuro State Junior High School 3 Odd Semester for Academic Year 2014-2015. The data obtained are formative test results, observation sheets of teaching and learning activities. From the results of analysts it was found that student achievement increased from cycle I to cycle III namely, cycle I (68.00\%), cycle II $(76.00 \%)$, cycle III $(88.00 \%)$. The conclusion of this study is that the cooperative method of the TAPPS model can positively influence the learning motivation of students of class VII B Candipuro SMP Negeri 3 Odd Semester Academic Year 2014-2015, and this learning model can be used as an alternative learning craft.

Keywords: Crafts, Cooperative Methods, Tapps.

\section{PENDAHULUAN}

Guru memiliki peran yang sangat penting dalam menentukan kuantitas dan kualitas pengajaran yang dilaksanakannya. Oleh sebab itu, guru harus memikirkan dan membuat 
perencanaan secara seksama dalam meningkatkan kesempatan belajar bagi siswanya dan memperbaiki kualitas mengajarnya.

Hal ini menuntut perubahan-perubahan dalam pengorganisasian kelas, penggunaan metode mengajar, strategi belajar-mengajar, maupun sikap dan karakteristik guru dalam mengelola proses belajar-mengajar, bertindak selaku administrator yang berusaha menciptakan kondisi belajar yang efektif sehingga siswa mampu untuk menyimak dan menguasi tujuan-tujuan pendidikan.

Untuk memenuhi hal tersebut di atas guru dituntut mampu mengelola proses belajar- mengajar yang memberikan rangsangan kepada siswa sehingga ia mau belajar karena siswalah subjek utama dalam belajar. Dalam mencinptakan kondisi belajarmengajar yang efektif harus ada partisipasi aktif dari siswa, apalagi dalam pembelajar Prakarya. Prakarya berfungsi untuk mengembangkan kemampuan bernalar melalui kegiatan penyelidikan, eksplorasi, dan eksperimen, sebagai alat pemecahan masalah melalui pola pikir dan model Prakarya serta sebagai alat komunikasi melalui symbol, table, grafik, diagram dalam menjelaskan gagasan.

Pembelajaran Prakarya tidak lagi mengutamakan pada penyerapan melalui pencapaian informasi, tetapi lebih mengutamakan pada pengembangan kemampuan dan pemrosesan informasi. Untuk itu aktivitas peserta didik perlu ditingkatkan melalui latihan-latihan atau tugas Prakarya dengan bekerja kelompok kecil dan menjelaskan ideide kepada orang lain. (Hartoyo, 2000: 24).

Pembelajaran kooperatif lebih menekankan interaksi antar siswa. Dari sini siswa akan melakukan komunikasi aktif dengan sesama temannya. Dengan komunikasi tersebut diharapkan siswa dapat menguasai materi pelajaran dengan mudah karena "siswa lebih mudah memahami penjelasan dari kawannya dibanding penjelasan dari guru karena taraf pengetahuan serta pemikiran mereka lebih sejalan dan sepadan". (Sulaiman dalam Wahyuni 2001: 2).

Penelitian juga menunjukkan bahwa pembelajaran kooperatif memiliki dampak yang amat positif terhadap siswa yang rendah hasil belajarnya. (Nur, 1996: 2). Berdasarkan paparan tersebut diatas maka peneliti ingin melakukan penelitian dengan judul "Penerapan Metode Kooperatif Model TAPPS Sebagai Upaya Meningkatkan Prestasi Belajar Prakarya Materi Pengolahan Pangan Buah dan Sayuran Pada Siswa Kelas VII B SMP Negeri 3 Candipuro Semester Ganjil Tahun Pelajaran 2014 - 2015”.

\section{RUMUSAN MASALAH}

Metode pembelajaran kooperatif Berdasarkan permasalahan di atas maka dapat dirumuskan suatu masalah:

1. Bagaimanakah peningkatan prestasi belajar siswa dengan diterapkannya model TAPPS pada siswa kelas VII B SMP Negeri 3 Candipuro Semester Ganjil Tahun Pelajaran 2014 - 2015? 
2. Bagaimanakah pengaruh metode pembelajaran kooperatif model TAPPS terhadap motivasi belajar siswa kelas VII B SMP Negeri 3 Candipuro Semester Ganjil Tahun Pelajaran 2014 - 2015?

\section{TUJUAN PENELITIAN}

Sesuai dengan permasalahan di atas, penelitian ini bertujuan untuk:

1. Ingin mengetahui peningkatan prestasi belajar siswa setelah diterapkannya metode pembelajaran kooperatif model TAPPS pada siswa kelas VII B SMP Negeri 3 Candipuro Semester Ganjil Tahun Pelajaran 2014 - 2015.

2. Ingin mengetahui pengaruh motivasi belajar siswa setelah diterapkan metode pembelajaran kooperatif model TAPPS pada siswa kelas VII B SMP Negeri 3 Candipuro Semester Ganjil Tahun Pelajaran 2014 - 2015.

\section{KAJIAN PUSTAKA}

Menurut (KBBI, 1996:14) pembelajaran merupakan proses, cara menjadikan orang atau makhhluk hidup belajar. Sedangkan belajar merupakan usaha untuk memperoleh kepandaian atau ilmu, berubah tingka laku atau tanggapan yang disebabkan oleh pengalaman. Sedangkan pada Pasal 1 Undang-undang No. 20 tahun 2000 menjelaskan mengenai pendidikan nasional yang menyebutkan bahwa pembelajaran adalah proses interaksi peserta didik dengan pendidik dan sumber belajar pada suatu lingkungan belajar. Berdasarkan dari penjelasan di atas maka dapat disimpulkan bahwa makna pembelajaran yaitu proses yang disengaja yang menyebabkan siswa belajar pada suatu lingkungan belajar untuk melakukan kegiatan pada situasi tertentu.

Pembelajaran kooperatif adalah suatu pengajaran yang melibatkan siswa untuk bekerja dalam kelompok-kelompok untuk menetapkan tujuan bersama. (Felder, 1994: 2). Sependapat dengan pernyataan tersebut Setyaningsih (2001: 8) mengemukakan bahwa metode pembelajaran kooperatif memusatkan aktivitas di kelas pada siswa dengan cara pengelompokan siswa untuk bekerjasama dalam proses pembelajaran. Dari dua pengertian di atas dapat disimpulkan bahwa pembelajaran kooperatif adalah suatu metode pembelajaran dengan cara mengelompokkan siswa ke dalam kelompok-kelompok kecil untuk bekerja sama dalam memecahkan masalah. Kemampuan siswa dalam setiap kelompok adalah hiterogen.

Model pembelajaran Kooperatif berbasis TAPPS (Thinking Aloud Pair Problem Solving) penerapannya yakni siswa mengerjakan permasalahan yang mereka jumpai secara berpasangan, dengan satu anggota pasangan berfungsi sebagai pemecah permasalahan dan yang lainnya sebagai pendengar. Pemecah permasalahan mengucapkan semua pemikiran dan mereka saat mereka mencari sebuah solusi, pendengar mendorong rekan mereka untuk tetap untuk berbicara dan menawarkan anggapan umum atau petunjuk jika bagian pemecah masalah tertekan. 


\section{METODE PENELITIAN}

Penelitian ini merupakan penelitian tindakan (action research), karena penelitian dilakukan untuk memecahkan masalah pembelajaran di kelas dengan tujuan untuk meningkatkan kemampuan siswa kelas VII B di SMP N 3 Candipuro dalam menerima materi dan juga memahami pelajaran terutama pada mata pelajaran prakarya yang mana diharapkan siswa dapat mecapai tujuan-tujuan dari pembelajaran. Penelitian ini bertempat di SMP N 3 Candipuro Lumajang dengan Subyek penelitian ini adalah siswa kelas VII B SMP N 3 Candipuro yang berjumlah 25 siswa pada semester ganjil tahun pelajaran 2014-2015. Waktu penelitian dilaksanakan pada semester ganjil tahun ajaran 2014-2015 mulai dari bulan sepetember.

\section{PROSEDUR PENELITIAN}

Penelitian ini langsung dilakukan di dalam kelas meliputi kegiatan pelaksanakan PTK berupa tes awal, refleksi dan observasi untuk mengidentifikasi permasalahan di kelas

Pada penelitian ini dilakukan dengan menggunakan tiga siklus:

1. Siklus I

a. Tahap Perencanaan

Pada tahap ini peneliti mempersiapkan perangkat pembelajaran yang terdiri dari rencana pelajaran 1 , LKS 1 , soal tes formatif 1 dan alat-alat pengajaran yang mendukung.

b. Tahap Kegiatan dan Pelaksanaan

Pelaksanaan kegiatan belajar mengajar untuk siklus I dilaksanakan pada tanggal 6 September 2014 di kelas VII B dengan jumlah siswa 25 siswa. Dalam hal ini peneliti bertindak sebagai guru. Adapun proses belajar mengajar mengacu pada rencana pelajaran yang telah dipersiapkan. Pengamatan (observasi) dilaksanakan bersamaan dengan pelaksaaan belajar mengajar.

c. Refleksi

Dalam pelaksanaan kegiatan belajar mengajar diperoleh informasi dari hasil pengamatan sebagai berikut:

1) Guru kurang baik dalam memotivasi siswa dan dalam menyampaikan tujuan pembelajaran

2) Guru kurang baik dalam pengelolaan waktu

3) Siswa kurang begitu antusias selama pembelajaran berlangsung.

Siklus II

a. Tahap perencanaan

Pada tahap ini peneliti mempersiapkan perangkat pembelajaran yang terdiri dari rencana pelajaran 2, LKS, 2, soal tes formatif II dan alat-alat pengajaran yang mendukung. 
b. Tahap kegiatan dan pelaksanaan

Pelaksanaan kegiatan belajar mengajar untuk siklus II dilaksanakan pada tanggal 13 September 2014 di kelas VII B dengan jumlah siswa 25 siswa. Dalam hal ini peneliti bertindak sebagai guru. Adapun proses belajar mengajar mengacu pada rencana pelajaran dengan memperhatikan revisi pada siklus I, sehingga kesalahan atau kekurangan pada siklus I tidak terulang lagi pada siklus II. Pengamatan (observasi) dilaksanakan bersamaan dengan pelaksanaan belajar mengajar

c. Refleksi

Dalam pelaksanaan kegiatan belajar diperoleh informasi dari hasil pengamatan sebagai berikut:

1) Memotivasi siswa

2) Membimbing siswa merumuskan kesimpulan/menemukan konsep

3) Pengelolaan waktu

\section{Siklus III}

a. Tahap Perencanaan

Pada tahap ini peneliti mempersiapkan perangkat pembelajaran yang terdiri dari rencana pelajaran 3 , LKS 3 , soal tes formatif 3 dan alat-alat pengajaran yang mendukung.

b. Tahap kegiatan dan pengamatan

Pelaksanaan kegiatan belajar mengajar untuk siklus III dilaksanakan pada tanggal 20 September 2014 di kelas VII B dengan jumlah siswa 25 siswa. Dalam hal ini peneliti bertindak sebagai guru. Adapun proses belajar mengajar mengacu pada rencana pelajaran dengan memperhatikan revisi pada siklus II, sehingga kesalahan atau kekurangan pada siklus II tidak terulang lagi pada siklus III. Pengamatan (observasi) dilaksanakan bersamaan dengan pelaksanaan belajar mengajar.

c. Refleksi

Pada tahap ini akan dikaji apa yang telah terlaksana dengan baik maupun yang masih kurang baik dalam proses belajar mengajar dengan penerapan metode pembelajaran kooperatif model TAPPS. Dari data-data yang telah diperoleh dapat diuraikan sebagai berikut:

1) Selama proses belajar mengajar guru telah melaksanakan semua pembelajaran dengan baik. Meskipun ada beberapa aspek yang belum sempurna, tetapi persentase pelaksanaannya untuk masing-masing aspek cukup besar.

2) Berdasarkan data hasil pengamatan diketahui bahwa siswa aktif selama proses belajar berlangsung.

3) Kekurangan pada siklus-siklus sebelumnya sudah mengalami perbaikan dan peningkatan sehingga menjadi lebih baik.

4) Hasil belajar siswa pada siklus III mencapai ketuntasan. 


\section{TEKNIK PENGUMPULAN DAN ANALISIS DATA}

Pengumpulan data dilakukan melalui observasi pada siswa dan guru padakeseluruhan kegiatan mulai dari awal pelaksanaan tindakan sampai dengan berakhirnya pelaksanaan tindakan. Tindakan berupa meningkatkan kemampuan siswa dalam memahami mata pelajaran prakarya dalam bab pengolahan bahan pangan dengan menggunakan metode pembelajaran TAPPS.

Analisis ini dihitung dengan menggunakan statistic sederhana yaitu:

1. Untuk menilai ulangan atau tes formatif

Peneliti melakukan penjumlahan nilai yan gdiperoleh siswa, yang selanjutnya dibagi dengan jumlah siswa yang ada di kelas tersebut sehingga diperoleh rata-rata tes formatif dapat dirumuskan:

$$
\bar{X}=\frac{\sum X}{\sum N}
$$

$$
\text { Keterangan }: \begin{aligned}
\bar{X} & =\text { Nilai rata-rata } \\
\Sigma \mathrm{X} & =\text { Jumlah semua nilai siswa } \\
\Sigma \mathrm{N} & =\text { Jumlah siswa }
\end{aligned}
$$

\section{Untuk ketuntasan belajar}

Ada dua kategori ketuntasan belajar yaitu secara perorangan dan secara klasikal. Berdasarkan petunju pelaksanaan belajar mengajar kurikulum 1994 (Depdikbud, 1994), yaitu seorang siswa telah tuntas belajar bila telah mencapai skor $65 \%$ atau nilai 65, dan kelas disebut tuntas belajar bila di kelas tersebut terdapat $85 \%$ yang telah mencapai daya serap lebih dari atau sama dengan $65 \%$. Untuk menghitung persentase ketuntasan belajar digunakan rumus sebagai berikut:

$$
P=\frac{\sum \text { Siswa.yang.tuntas.belajar }}{\sum \text { Siswa }} \times 100 \%
$$

\section{Untuk lembar observasi}

a. Lembar observasi pengelola metode pembelajarn koooperatif model TAPPS.

Untuk menghitung lembar observasi pengelolaan metode pembelajaran kooperatif model TAPPS digunakan rumus sebagai berikut :

$$
\overline{\mathrm{X}}=\frac{P 1+P 2}{2}
$$

$$
\text { Dimana P1 = Pengamat } 1 \text { dan } \mathrm{P} 2=\text { Pengamat } 2
$$

b. Lembar observasi aktifitas guru dan siswa

Untuk menghitung lembar observasi aktifitas guru dan siswa digunakan rumus sebagai berikut : 


$$
\begin{aligned}
& \%=\frac{\bar{x}}{\Sigma x} \times 100 \% \text { dengan } \\
& \overline{\mathrm{X}}=\frac{\text { Jumah.hasil.pengama } \tan }{\text { Jumlah.pengama } \tan }=\frac{P 1+P 2}{2} \\
& \text { Dimana: } \frac{\%}{\mathrm{X}}=\text { Presentase pengamatan } \\
& \overline{\mathrm{X}} \quad=\text { Rata-rata } \\
& \sum \overline{\mathrm{x}}=\text { Jumlah rata-rata } \\
& \mathrm{P} 1=\text { Pengamat } 1 \\
& \mathrm{P} 2=\text { Pengamat } 2
\end{aligned}
$$

\section{HASIL DAN PEMBAHASAN}

Penelitian ini berbentuk penelitian tindakan kelas yang dilakukan di SMP N 3 Candipuro di kelas VII B. dimana pembelajaran ini dilaksanakan dengan menggunakan model pembelajaran Thinking Aloud Pair Problem Solving (TAPPS) untuk meningkatkan pemahaman siswa dalam materi pengolahan bahan makanan pada mata pelajaran prakarya dengan tujuan akahir untuk meningkatkan prestasi belajar dari siswa.

Penelitian ini terdiri dari 3 siklus dimana pada masing masing siklus terdiri dari 1 pertemuan. Siswa dinyatakan tuntas belajar apabila $\mathrm{P} \geq 70$.

Tabel 1. Pengelolaan Pembelajaran Pada Siklus I

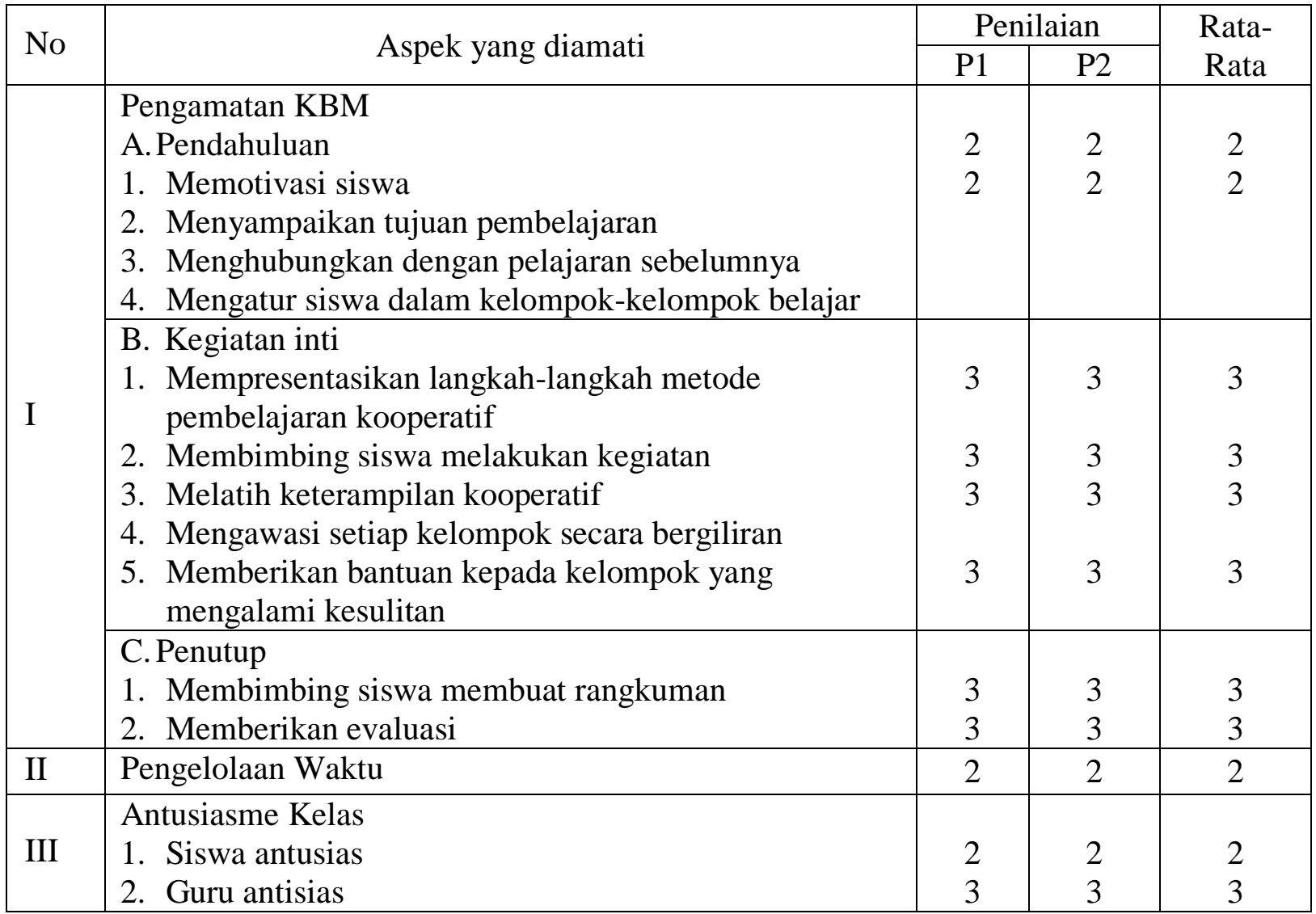


Keterangan : Nilai : Kriteria :

1) : Tidak Baik

2) : Kurang Baik

3) : Cukup Baik

4) : Baik

Berdasarkan tabel di atas aspek-aspek yang mendapatkan kriteria kurang baik adalah memotivasi siswa, menyampaikan tujuan pembelajran, pengelolaan waktu, dan siswa antusias. Keempat aspek yang mendapat nilai kurang baik di atas, merupakan suatu kelemahan yang terjadi pada siklus I dan akan dijadikan bahan kajian untuk refleksi dan revisi yang akan dilakukan pada siklus II.

Hasil observasi berikutnya adalah aktivitas guru dan siswa seperti pada tabel berikut:

Tabel 2. Pengelolaan Pembelajaran Pada Siklus I

\begin{tabular}{|r|l|r|}
\hline No & Aktivitas Guru yang diamati & $\%$ \\
\hline & Menyampaikan tujuan & 5,0 \\
2 & Memotivasi siswa & 8,3 \\
3 & Mengkaitkan dengan pelajaran sebelumnya & 8,3 \\
4 & Menyampaikan materi/ langkah-langkah/ strategi & 6,7 \\
5 & Membimbing dan mengamati siswa dalam menemukan konsep & 13,3 \\
6 & Meminta siswa menyajikan dan mendiskusikan hasil kegiatan & 21,7 \\
7 & Memberikan umpan balik & 10,0 \\
9 & Membimbing siswa merangkum pelajaran & 18,3 \\
& & 8,3 \\
\hline No & Aktivitas siswa yang diamati & $\%$ \\
\hline & Mendengarkan/ memperhatikan penjelasan guru & 22,5 \\
1 & Membaca buku & 11,5 \\
2 & Bekerja dengan sesama anggota kelompok & 18,7 \\
3 & Diskusi antar siswa/ antara siswa dengan guru & 14,4 \\
4 & Menyajikan hasil pembelajaran & 2,9 \\
5 & Menyajikan/ menanggapi pertanyaan/ ide & 5,2 \\
6 & Menulis yang relevan dengan KBM & 8,9 \\
7 & Merangkum pembelajaran & 6,9 \\
9 & Mengerjakan tes evaluasi & 8,9 \\
\hline
\end{tabular}


Berdasarkan tabel di atas tampak bahwa aktivitas guru yang paling dominan pada siklus I adalah membimbing dan mengamati siswa dalam menemukan konsep, yaitu 21,7 $\%$. Aktivitas lain yang presentasinya cukup besar adalah memberi umpan balik/ evaluasi, tanya jawab dan menjelaskan materi yang sulit yaitu masing-masing sebesar 13,3\%. Sedangkan aktivitas siswa yang paling dominan adalah mengerjakan/ memperhatikan penjelasan guru yaitu 22,5\%. Aktivitas lain yang presentasinya cukup besar adalah bekerja dengan sesama anggota kelompok, diskusi antara siswa/ antara siswa dengan guru, dan membaca buku yaitu masing-masing $18,7 \%$ 14,4 dan 11,5\%.

Tabel 3. Hasil Tes Formatif Siswa Siklus I

\begin{tabular}{|c|c|c|c|c|c|c|c|}
\hline \multirow{2}{*}{$\begin{array}{l}\text { No. } \\
\text { Urut }\end{array}$} & \multirow{2}{*}{ Skor } & \multicolumn{2}{|c|}{ Keterangan } & \multirow{2}{*}{ No. Urut } & \multirow{2}{*}{ Skor } & \multicolumn{2}{|c|}{ Keterangan } \\
\hline & & $\mathrm{T}$ & TT & & & $\mathrm{T}$ & TT \\
\hline 1 & 40 & & $\sqrt{ }$ & 14 & 80 & $\sqrt{ }$ & \\
\hline 2 & 80 & $\sqrt{ }$ & & 15 & 70 & $\sqrt{ }$ & \\
\hline 3 & 50 & & $\sqrt{ }$ & 16 & 40 & & $\sqrt{ }$ \\
\hline 4 & 60 & & $\sqrt{ }$ & 17 & 80 & $\sqrt{ }$ & \\
\hline 5 & 80 & $\sqrt{ }$ & & 18 & 50 & & $\sqrt{ }$ \\
\hline 6 & 70 & $\sqrt{ }$ & & 19 & 80 & $\sqrt{ }$ & \\
\hline 7 & 30 & & $\sqrt{ }$ & 20 & 70 & $\sqrt{ }$ & \\
\hline 8 & 90 & $\sqrt{ }$ & & 21 & 70 & $\sqrt{ }$ & \\
\hline 9 & 70 & $\sqrt{ }$ & & 22 & 70 & $\sqrt{ }$ & \\
\hline 10 & 70 & $\sqrt{ }$ & & 23 & 40 & & $\sqrt{ }$ \\
\hline 11 & 80 & $\sqrt{ }$ & & 24 & 80 & $\sqrt{ }$ & \\
\hline 12 & 60 & & $\sqrt{ }$ & 25 & 70 & $\sqrt{ }$ & \\
\hline 13 & 70 & $\sqrt{ }$ & & & & & \\
\hline Jumlah & 850 & 8 & 5 & Jumlah & 800 & 9 & 3 \\
\hline $\begin{array}{l}\text { Jumlah } \\
\text { Jumlah } \\
\text { Rata-Ra }\end{array}$ & $\begin{array}{l}\text { kor } 165 \\
\text { kor Ma } \\
\text { a Skor }\end{array}$ & $\begin{array}{l}\text { al Id } \\
\text { apai }\end{array}$ & 500 & & & & \\
\hline
\end{tabular}

Tabel 4. Rekapituasi Hasil Tes Formatif Siswa pada Siklus I

\begin{tabular}{|l|l|l|}
\hline No & \multicolumn{1}{|c|}{ Uraian } & Hasil Siklus I \\
\hline 1 & Nilai rata-rata tes formatif & 66,00 \\
2 & Jumlah siswa yang tuntas belajar & 17 \\
3 & Persentase ketuntasan belajar & 68,00 \\
\hline
\end{tabular}

Dari tabel di atas dapat dijelaskan bahwa nilai rata-rata prestasi belajar siswa adalah 66,00 dan ketuntasan belajar mencapai 68,00\% atau ada 17 siswa dari 25 siswa sudah tuntas belajar. Hasil tersebut menunjukkan bahwa pada siklus pertama secara klasikal 
siswa belum tuntas belajar, karena siswa yang memperoleh nilai $\geq 65$ hanya sebesar $68,00 \%$ lebih kecil dari persentase ketuntasan yang dikehendaki yaitu sebesar $85 \%$. Hal ini disebabkan karena siswa masih merasa baru dan belum mengerti apa yang dimaksudkan dan digunakan guru dengan menerapkan metode pembelajaran kooperatif model TAPPS.

Tabel 2. Pengelolaan Pembelajaran Pada Siklus II

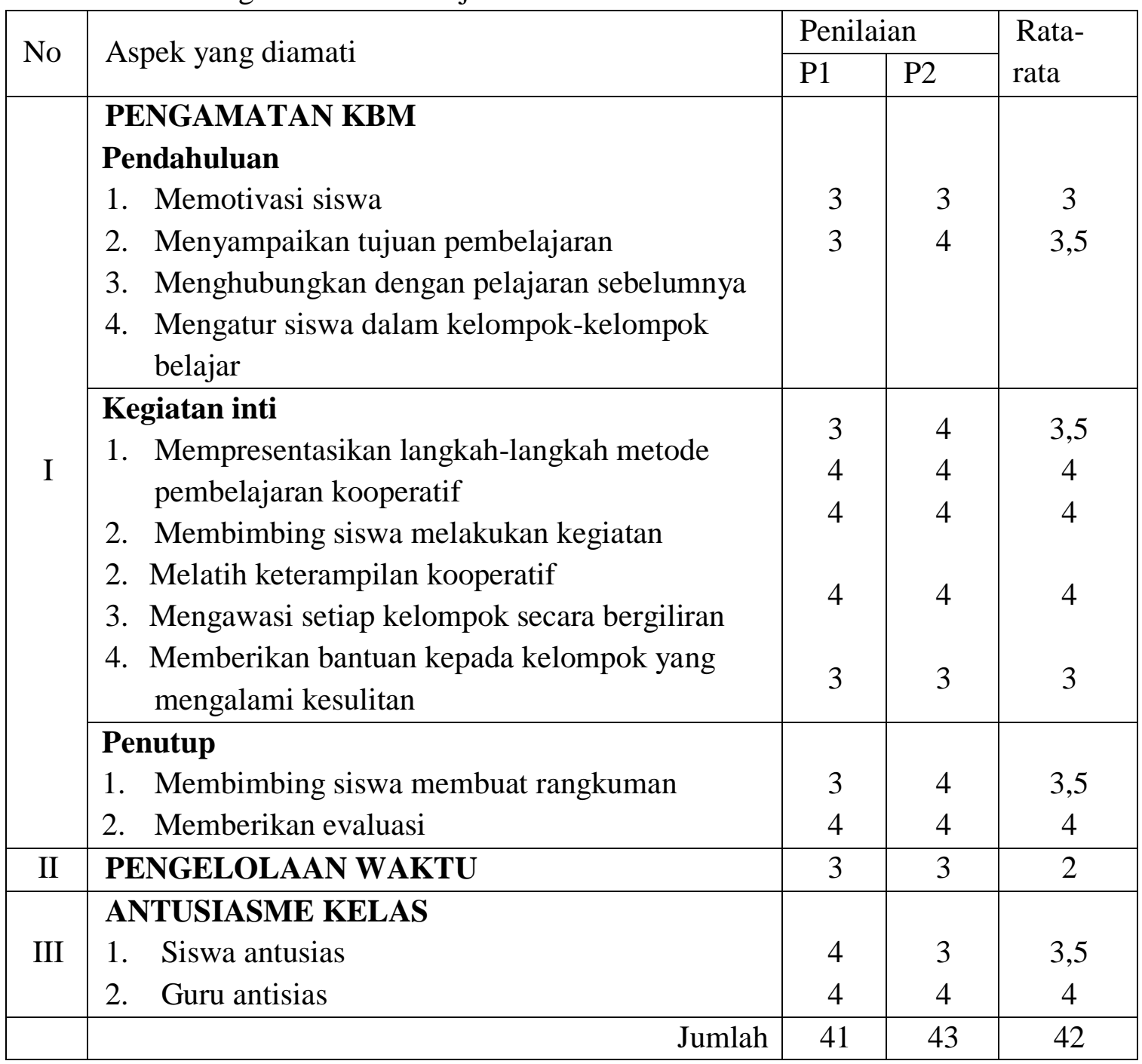

Keterangan : Nilai : Kriteria
1) : Tidak Baik
2) : Kurang Baik
3) : Cukup Baik
4) : Baik

Dari tabel di atas, tanpak aspek-aspek yang diamati pada kegiatan belajar mengajar (siklus II) yang dilaksanakn oleh guru dengan menerapkan metode pembelajarn 
kooperatif model TAPPS mendapatkan penilaian yang cukup baik dari pengamat. Namun ada beberapa aspek yang perlu mendapatkan perhatian untuk penyempurnaan penerapan pembelajaran selanjutnya seperti memotivasi siswa, membimbing siswa merumuskan kesimpulan/menemukan konsep, dan pengelolaan waktu.

Tabel 3. Aktivitas Guru Dan Siswa Pada Siklus II

\begin{tabular}{|c|l|c|}
\hline No & Aktivitas Guru yang diamati & $\%$ \\
\hline 1 & Menyampaikan tujuan & 6,7 \\
2 & Memotivasi siswa & 6,7 \\
3 & Mengkaitkan dengan pelajaran sebelumnya & 6,7 \\
4 & Menyampaikan materi/ langkah-langkah/strategi & 11,7 \\
5 & Menjelaskan materi yang sulit & 11,7 \\
6 & Membimbing dan mengamati siswa dalam menemukan konsep & 25,0 \\
7 & Meminta siswa menyajikan dan mendiskusikan hasil kegiatan & 8,2 \\
8 & Memberikan umpan balik & 16,6 \\
9 & Membimbing siswa merangkum pelajaran & 6,7 \\
\hline No & Aktivitas siswa yang diamati & $\%$ \\
\hline 1 & Mendengarkan/ memperhatikan penjelasan guru & 17,9 \\
2 & Membaca buku & 12,1 \\
3 & Bekerja dengan sesama anggota kelompok & 21,0 \\
4 & Diskusi antar siswa/ antara siswa dengan guru & 13,8 \\
5 & Menyajikan hasil pembelajaran & 4,6 \\
6 & Menyajikan/ menanggapi pertanyaan/ ide & 5,4 \\
7 & Menulis yang relevan dengan KBM & 7,7 \\
8 & Merangkum pembelajaran & 6,7 \\
9 & Mengerjakan tes evaluasi & 10,8 \\
\hline
\end{tabular}

Berdasarkan tabel di atas, aktifitas guru yang paling dominan pada siklus II adalah membimbing dan mengamati siswa dalam menentukan konsep yaitu $25 \%$. Jika dibandingkan dengan siklus I, aktivitas ini mengalami peningkatan. Aktivitas guru yang mengalami penurunan adalah memberi umpan balik/evaluasi/ Tanya jawab (16,6\%), mnjelaskan materi yang sulit $(11,7)$. Meminta siswa mendiskusikan dan menyajikan hasil kegiatan $(8,2 \%)$, dan membimbing siswa merangkum pelajaran $(6,7 \%)$.

Sedangkan untuk aktivitas siswa yang paling dominan pada siklus II adalah bekerja dengan sesama anggota kelompok yaitu (21\%). Jika dibandingkan dengan siklus I, aktifitas ini mengalami peningkatan. Adapun aktifitas siswa yang mengalami peningkatan adalah membaca buku, menyajikan hasil pembelajaran,menanggapi dan mengerjakan tes evaluasi .

Aktifitas siswa yang mengalami penurunan adalah mendengarkan/memperhatikan penjelasan guru (Diskusi antar siswa/ antara siswa dengan guru ,menulis yang relevan dengan KBM dan merangkum pembelajaran). 
Tabel 4. Hasil Tes Formatif Siklus II

\begin{tabular}{|c|c|c|c|c|c|c|c|}
\hline \multirow{2}{*}{$\begin{array}{l}\text { No. } \\
\text { Urut }\end{array}$} & \multirow{2}{*}{ Skor } & \multicolumn{2}{|c|}{ Keterangan } & \multirow{2}{*}{$\begin{array}{l}\text { No. } \\
\text { Urut }\end{array}$} & \multirow{2}{*}{ Skor } & \multicolumn{2}{|c|}{ Keterangan } \\
\hline & & $\mathrm{T}$ & TT & & & $\mathrm{T}$ & TT \\
\hline 1 & 50 & & $\sqrt{ }$ & 14 & 70 & $\sqrt{ }$ & \\
\hline 2 & 90 & $\sqrt{ }$ & & 15 & 70 & $\sqrt{ }$ & \\
\hline 3 & 60 & & $\sqrt{ }$ & 16 & 50 & & $\sqrt{ }$ \\
\hline 4 & 70 & $\sqrt{ }$ & & 17 & 80 & $\sqrt{ }$ & \\
\hline 5 & 80 & $\sqrt{ }$ & & 18 & 60 & & $\sqrt{ }$ \\
\hline 6 & 70 & $\sqrt{ }$ & & 19 & 80 & $\sqrt{ }$ & \\
\hline 7 & 40 & & $\sqrt{ }$ & 20 & 80 & $\sqrt{ }$ & \\
\hline 8 & 100 & $\sqrt{ }$ & & 21 & 80 & $\sqrt{ }$ & \\
\hline 9 & 80 & $\sqrt{ }$ & & 22 & 70 & $\sqrt{ }$ & \\
\hline 10 & 90 & $\sqrt{ }$ & & 23 & 60 & & $\sqrt{ }$ \\
\hline 11 & 90 & $\sqrt{ }$ & & 24 & 80 & $\sqrt{ }$ & \\
\hline 12 & 70 & $\sqrt{ }$ & & 25 & 90 & $\sqrt{ }$ & \\
\hline 13 & 80 & $\sqrt{ }$ & & Jumlah & 870 & 9 & 3 \\
\hline Jumlah & 970 & 10 & 3 & & & & \\
\hline & $\begin{array}{l}\text { Jumlal } \\
\text { Jumlal } \\
\text { Rata-R }\end{array}$ & $\begin{array}{l}\text { cor } 1 \\
\text { ror } \mathrm{N} \\
\text { Sko }\end{array}$ & $\begin{array}{l}\text { mal } \\
\text { capa }\end{array}$ & $\begin{array}{l}12500 \\
60\end{array}$ & & & \\
\hline
\end{tabular}

Dari tabel di atas diperoleh nilai rata-rata prestasi belajar siswa adalah 73,60\% dan ketuntasan belajar mencapai 76,00\% atau ada 19 siswa dari 25 siswa sudah tuntas belajar. Hasil ini menunjukkan bahwa pada siklus II ini ketuntasan belajar secara klasikal telah mengalami peningkatan sedikit lebih baik dari siklus I. Adanya peningkatan hasil belajar siswa ini karena setelah guru menginformasikan bahwa setiap akhir pelajaran akan selalu diadakan tes sehingga pada pertemuan berikutnya siswa lebih termotivasi utnuk belajar. Selain itu siswa juga sudah mulai mengerti apa yang dimaksudkan dan dinginkan guru dengan menerapkan metode pembelajaran kooperatif model TAPPS. 
Tabel 5. Pengelolaan Pembelajaran Pada Siklus III

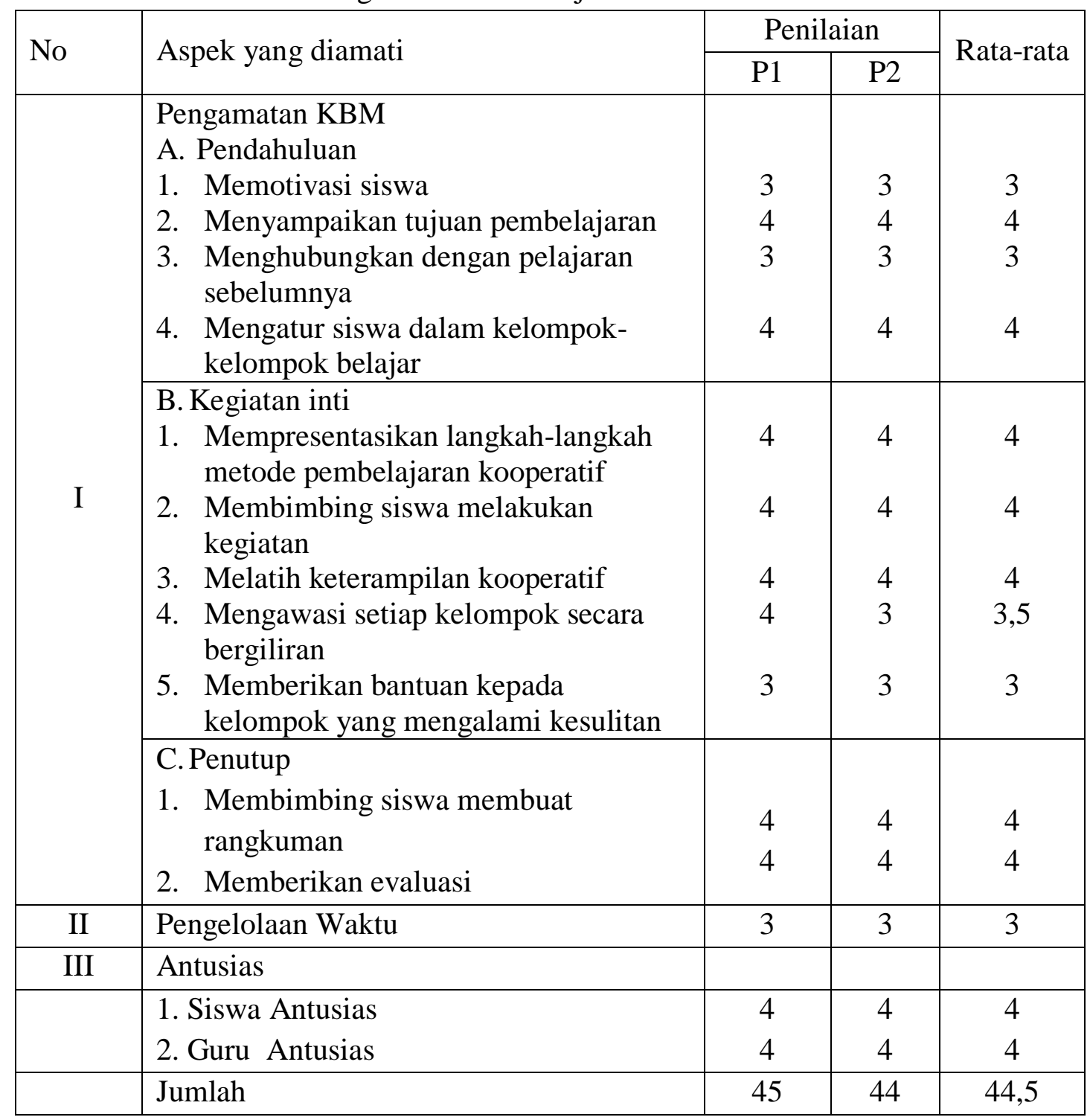

Keterangan : NilaI : Kriteria
1) : Tidak Baik
2) : Kurang Baik
3) : Cukup Baik
4) : Baik

Dari tabel di atas, dapat dilihat aspek-aspek yang diamati pada kegiatan belajar mengajar (siklus III) yang dilaksanakan oleh guru dengan menerapkan metode pembelajaran kooperatif model TAPPS mendapatkan penilaian cukup baik dari pengamat adalah memotivasi siswa, membimbing siswa merumuskan kesimpulan/menemukan konsep, dan pengelolaan waktu. 
Tabel 6. Aktivitas Guru dan Siswa Pada Siklus III

\begin{tabular}{|c|l|c|}
\hline No & Aktivitas Guru yang diamati & $\%$ \\
\hline 1 & Menyampaikan tujuan & 6,7 \\
2 & Memotivasi siswa & 6,7 \\
3 & Mengkaitkan dengan pelajaran sebelumnya & 10,7 \\
4 & Menyampaikan materi/ langkah-langkah/ strategi & 13,3 \\
5 & Menjelaskan materi yang sulit & 10,0 \\
6 & Membimbing dan mengamati siswa dalam menemukan konsep & 22,6 \\
7 & Meminta siswa menyajikan dan mendiskusikan hasil kegiatan & 10,0 \\
8 & Memberikan umpan balik & 11,7 \\
9 & Membimbing siswa merangkum pelajaran & 10,0 \\
\hline No & Aktivitas siswa yang diamati & $\%$ \\
\hline 1 & Mendengarkan/ memperhatikan penjelasan guru & 20,8 \\
2 & Membaca buku & 13,1 \\
3 & Bekerja dengan sesama anggota kelompok & 22,1 \\
4 & Diskusi antar siswa/ antara siswa dengan guru & 15,0 \\
5 & Menyajikan hasil pembelajaran & 2,9 \\
6 & Menyajikan/ menanggapi pertanyaan/ ide & 4,2 \\
7 & Menulis yang relevan dengan KBM & 6,1 \\
8 & Merangkum pembelajaran & 7,3 \\
9 & Mengerjakan tes evaluasi & 8,5 \\
\hline
\end{tabular}

Berdasarkan tabel diatas tampak bahaw aktivitas guru yang paling dominan pada siklus III adalah membimbing dan mengamati siswa dalam menemukan konsep yaitu 22,6\%. Sedangkan untuk aktivitas siswa yang paling dominan pada siklus III adalah bekerja dengan sesama anggota kelompok yaitu $(22,1 \%)$ dan mendengarkan/memperhatikan penjelasan guru (20,8\%), aktivitas yang mengalami peningkatan adalah membaca buku siswa $(13,1 \%)$ dan diskusi antar siswa/antara siswa dengan guru $(15,0 \%)$. Sedangkan aktivitas yang lainnya mengalami penurunan.

Tabel 7. Hasil Tes Formatif Siklus III

\begin{tabular}{|c|c|c|c|c|c|c|c|}
\hline \multirow{2}{*}{$\begin{array}{l}\text { No. } \\
\text { Urut }\end{array}$} & \multirow{2}{*}{ Skor } & \multicolumn{2}{|c|}{ Keterangan } & \multirow{2}{*}{ No. Urut } & \multirow{2}{*}{ Skor } & \multicolumn{2}{|c|}{ Keterangan } \\
\hline & & $\mathrm{T}$ & TT & & & $\mathrm{T}$ & TT \\
\hline 1 & 60 & & $\sqrt{ }$ & 14 & 80 & $\sqrt{ }$ & \\
\hline 2 & 90 & $\sqrt{ }$ & & 15 & 90 & $\sqrt{ }$ & \\
\hline 3 & 70 & $\sqrt{ }$ & & 16 & 70 & $\sqrt{ }$ & \\
\hline 4 & 90 & $\sqrt{ }$ & & 17 & 80 & $\sqrt{ }$ & \\
\hline 5 & 80 & $\sqrt{ }$ & & 18 & 80 & $\sqrt{ }$ & \\
\hline 6 & 90 & $\sqrt{ }$ & & 19 & 90 & $\sqrt{ }$ & \\
\hline
\end{tabular}




\begin{tabular}{|c|c|c|c|c|c|c|c|}
\hline 7 & 50 & & $\sqrt{ }$ & 20 & 80 & $\sqrt{ }$ & \\
\hline 8 & 100 & $\sqrt{ }$ & & 21 & 80 & $\sqrt{ }$ & \\
\hline 9 & 80 & $\sqrt{ }$ & & 22 & 90 & $\sqrt{ }$ & \\
\hline 10 & 90 & $\sqrt{ }$ & & 23 & 60 & & $\sqrt{ }$ \\
\hline 11 & 90 & $\sqrt{ }$ & & 24 & 90 & $\sqrt{ }$ & \\
\hline 12 & 80 & $\sqrt{ }$ & & 25 & 90 & $\sqrt{ }$ & \\
\hline 13 & 80 & $\sqrt{ }$ & & Jumlah & 980 & 11 & 1 \\
\hline Jumlah & 1050 & 11 & 2 & & & & \\
\hline $\begin{array}{l}\mathrm{Ju} \\
\mathrm{Ju} \\
\mathrm{R}\end{array}$ & $\begin{array}{l}\text { lah Sko } \\
\text { lah Sko } \\
\text { a-Rata S }\end{array}$ & $\begin{array}{l}30 \\
\text { aksima } \\
\text { Tercap }\end{array}$ & $\begin{array}{l}1250 \\
20\end{array}$ & & & & \\
\hline
\end{tabular}

Tabel 8 Hasil Tes Formatif Siklus III

\begin{tabular}{|l|l|l|}
\hline No & Uraian & Hasil Siklus III \\
\hline 1 & Nilai rata-rata tes formatif & 81,20 \\
2 & Jumlah siswa yang tuntas belajar & 22 \\
3 & Persentase ketuntasan belajar & 88,00 \\
\hline
\end{tabular}

Berdasarkan dari hasil tes formatif yang dilakukan selama tiga siklus dengan menggunakan metode pembelajaran TAPPS dapat disimpulkan bahwa ada peningkatan ketuntasan belajar siswa dengan nilai prosentase $29,4 \%$.

\section{PENUTUP}

\section{KESIMPULAN}

Dari hasil kegiatan pembelajaran yang telah dilakukan selama tiga siklus, dan berdasarkan seluruh pembahasan serta analisis yang telah dilakukan dapat disimpulkan sebagai berikut:

1. Pembelajaran dengan kooperatif model TAPPS memiliki dampak positif dalam meningkatkan prestasi belajar siswa yang ditandai dengan peningkatan ketuntasan belajar siswa di kelas VII B SMP N 3 Candipuro dalam setiap siklus, yaitu siklus I $(68,00 \%)$, siklus II $(76,00 \%)$, siklus III $(88,00 \%)$.

2. Penerapan metode pembelajaran kooperatif model TAPPS mempunyai pengaruh positif, yaitu dapat meningkatkan motivasi belajar siswa siswa di kelas VII B SMP N 3 Candipuro yang ditunjukan dengan hasil wawancara dengan beberapa siswa, rata-rata jawaban siswa menyatakan bahwa siswa tertarik dan berminat dengan metode pembelajaran kooperatif model TAPPS sehingga mereka menjadi termotivasi untuk belajar. 


\section{SARAN}

Dari hasil penelitian yang diperoleh dari uraian sebelumnya agar proses belajar mengajar Prakarya lebih efektif dan lebih memberikan hasil yang optimal bagi siswa, maka disampaikan saran sebagai berikut: Untuk melaksanakan metode pembelajaran kooperatif model TAPPS memerlukan persiapan yang cukup matang, sehingga guru harus mampu menentukan atau memilih topik yang benar-benar bisa diterapkan dengan model kooperatif model TAPPS dalam proses belajar mengajar sehingga diperoleh hasil yang optimal.

\section{DAFTAR RUJUKAN}

Felder, Richard M. 1994. Cooperative Learning in Technical Corse, (online), (Pcll ldlMy $\%$ DocumentlCoop \% 20 Report.

Hartoyo. 2000. Dasar-dasar Interaksi Belajar Mengajar. Surabaya: Usaha Nasional

KBBI. 1996. Edisi Kedua. Jakarta: Balai Pustaka.

Nur, Muhammad. 1996. Pembelajaran Kooperatif. Surabaya. Universitas Negeri Surabaya.

Setyaningsih, 2001, Metode Pembelajaran Kooperatif, halaman 8

Sulaiman,Wahyuni. 2001. Upaya Peningkatan Motivasi Belajar. Bandung: Sinar Baru Algesindon 